\title{
\|nTERSECTIONALITY, IDENTITY, AND THE RIDDLE OF CLASS
}

\section{Interseccionalidad, identidad y el enigma de la clase}

\author{
Sandro Mezzadra* \\ Universitá di Bologna (Italia)
}

\section{Keywords}

Identity Intersectionality

Black feminism

Oppression

Exploitation

\section{Palabras clave}

Identidad Interseccionalidad Feminismo negro Opresión Explotación
ABSTRACT: In this essay I discuss a specific notion that has become particularly influential in framing the discussion of identity and identity politics: intersectionality. I show that the original formulation of that notion was crucially intertwined with debates on class and class politics. After shedding light on the "prehistory" of intersectionality in black feminism, I discuss the original formulations of the concept in the works of Kimberle Crenshaw and Patricia Hill Collins. A focus on the notion of "oppression" as well as on the tensions between "irreducibility" and "simultaneity" of systems of oppression in intersectional writings leads me to examine some of the pitfalls of identity politics today. An attempt to rethink the notion of class in the light of intersectionality closes the essay.

RESUMEN: En este trabajo discuto una noción que se ha convertido en particularmente influyente en el marco de las discusiones sobre identidad y políticas de identidad: interseccionalidad. Muestro que la formulación original de esa noción estuvo irremediablemente relacionada con debates sobre la clase y las políticas de clase. Tras abordar la "prehistoria» de la insterseccionalidad en los feminismos negros, discuto las formulaciones originales del concepto a través de los trabajos de Kimberlé Crenshaw y Patricia Hill Collins. Atender a la noción de "opresión», así como a las tensiones entre «irreductibilidad» y «simultaneidad» de los sistemas de opresión que encontramos en los escritos sobre interseccionalidad, me permite examinar algunos de las trampas de las políticas de identidad. Cierro el texto con una propuesta de replanteamiento de la noción de clase a la luz de la interseccionalidad.

\footnotetext{
* Correspondence to: Sandro Mezzadra. Universitá di Bologna, Department of the Arts - Political Philosophy. Via Barberia, 4, 40123 Bologna - sandro.mezzadra@ unibo.it - http://orcid.org/0000-0002-5592-824X.

How to cite: Mezzadra, Sandro (2021). «Intersectionality, Identity, and the Riddle of Class». Papeles del CEIC, vol. 2021/2, heredada 3, 1-10. (http://doi.org/10.1387/
} pceic.22759).

Received: April, 2021 / Final version: May, 2021.

ISSN 1695-6494 / (C) 2021 UPV/EHU 
While identity is of course a fundamental category in European philosophy at least since Aristotle, its politicization is a much more recent phenomenon. One can say that it is only in the second half of the $20^{\text {th }}$ century that the development of cultural anthropology and sociology lays the theoretical ground for such a politicization, which is unconceivable without taking into account the emergence in many parts of the world of feminist movements as well as of a panoply of struggles against racial domination and for the rights of "minorities". Such important debates, as the one surrounding multiculturalism, contributed to foster identity politics and more generally to nurture a coding of politics in terms of (cultural) identity. Claims based upon identity played an important role in denouncing the presumed "neutrality" and even universalism of political institutions and in shedding light on the continuity of past histories of conquest and domination. This was for instance the case in settler colonial countries like Australia, Canada, and the United States with respect to the condition of indigenous peoples. More generally, identity provided a language for the articulation of claims and desires for liberation of a multiplicity of subjects whose oppression was predicated upon specific systems of oppression that were not targeted as such by established traditions of emancipatory politics. Struggles of racialized people or sexual minorities are good instances in this respect as well as claims proliferating within feminism along the lines that fracture the unitary figures of "the woman" and "universal sisterhood" (just think of the debates surrounding "postcolonial feminism" since the 1980s).

From this point of view, it is not surprising that one of the first polemical targets of identity politics was the concept of class and class politics. If one takes class as a collective subject (and even as a collective identity) whose unity and homogeneity are immediately given as an "objective" outcome of the relations of production, it is easy to see that there is no space here for a politics capable to grasp claims and movements articulated in specific terms -be it in gender or racial terms-. There is no shortage of historical examples of such conflicts and clashes within the labor movement. Take for instance B.R. Ambedkar, the great spokesperson of the Dalits in colonial India. In the late 1920s he had several debates with the leaders of the Communist Party of India, always pointing to the peculiarity of the position of the Dalits and to the spread of practices of untouchability in the world of labor and emphasizing the need to give priority to those questions in labor politics. This is precisely what Communist leaders did not want to accept, leading to a split with Ambedkar (Roy, 2016: 110). The latter, in his The Annihilation of Caste (1936), took stock of those debates writing that caste is "a division of laborers", and even more precisely "it is a hierarchy in which the divisions of laborers are graded one above the other" (Ambedkar, 2016: 233-234). The question of caste is directly addressed here from the point of view of what we could call the composition of labor, of the disruption of its unity as a sociological factor and as a political subject. And Ambedkar points to the relevance of conflicts within the ranks of workers - conflicts that played an important role elsewhere in the world, for instance in the relation between African American struggles and the labor movement in the United States ${ }^{1}$-.

In this essay I will discuss a specific notion that has become particularly influential in framing the discussion of identity and identity politics: intersectionality. I will show that the original formulation of that notion was crucially intertwined with debates on class and class politics.

1 See, for instance: Roediger (1991). 
At the same time, my argument is inspired by a theoretical and political concern with the main forms of contemporary identity politics, which are nurtured by such notions as "white privilege" and by "decolonial" language and theories (Mezzadra, 2021: 30-33). While I remain wary of the moralistic tones of identity politics today, what troubles me more is the tendency to simply affirm a subaltern identity as a closed and bordered one (often in the framework of a race to establish that identity as the most oppressed and humiliated). This makes alliances, convergences, and coalitions - as well as opposition- ultimately impossible (Haider, 2018: 40). It is against this background that I ask in the last section of the essay whether it is possible, and even necessary, to rethink the very concept of class to open up a different political perspective for struggles and movements as the ones that are at the center of theories of intersectionality. Needless to say, this requires going beyond the traditional notion of class that I have sketched above, I admit, providing a kind of caricature.

\section{INTERSECTIONALITY, SO WHAT?}

There is something important that must be stressed at the outset of this section. Over the last few years, the notion of intersectionality, originally forged in the United States, began to travel. And as is often the case with "traveling theories" (Said, 1983, 1994), it acquired new meanings and was in a way even reinvented first of all in the streets, outside of the academia. This happened in particular in the framework of the new wave of feminist movements in Latin America and Southern Europe, often using the slogan Ni Una Menos ("No one less"). In Argentina and Brazil, the notion of intersectionality is used to articulate and connect the movements and claims of indigenous and black women, rural and metropolitan communities, sexual minorities and women living in slums, without losing sight of their specificity, while in Italy and Spain it allows addressing issues of migration, colonialism, and sexuality. In a way, one can say that this appropriation and these uses of intersectionality prompted a re-politicization of the notion, where what is at stake, to quote the words of Angela Davis, is "not so much intersectionality of identities but intersectionality of struggles" (Davis, 2016: 144). Interestingly, this notion of intersectionality also played outstanding roles in the debates within the massive movement for black lives and against police brutality in the United States in the summer of $2020^{2}$.

I spoke of a re-politicization of intersectionality because over the last years in the United States the notion had become a kind of standard academic reference and its original political imprint had been to some extent neutralized (which does not mean of course that there were not many scholars continuing to do a very interesting and even radical work in the framework of intersectionality $\left.{ }^{3}\right)$. This is why there is a need to go back to the origin of the notion, and even beyond that to shortly reconstruct its genealogy. As I anticipated above, the reference to the world of work is foundational for intersectionality. Kimberlé Crenshaw, who is usually credited to have "invented" the notion, defines it as follows. Intersectionality, she writes, designates "the various ways in which race and gender interact to shape the multiple dimensions of Black women's employment experiences" (Crenshaw, 1991: 1244). Discussing the De Graffenreid v. General Motors case of 1977, in which the court rejected the claim of five black women

\footnotetext{
See, for instance: Thompson (2020).
}

See, for example: Nash (2019). 
that the company's seniority system discriminated against them, Crenshaw famously writes that the court's refusal to acknowledge "combined race and sex discrimination" rested on the assumption "that the boundaries of sex and race discrimination are defined respectively by white women's and black men's experiences" (Crenshaw, 1989: 143). The interplay of those boundaries effectively obscures and deletes a specific subjective experience within the ranks of workers, the one of black women. In focusing on such a neglected difference, intersectionality sets out to shed light on the parallel working of systems of oppression and domination that hierarchize the working class.

Writing in 1989, Kimberlé Crenshaw was aware of the fact that the notion of intersectionality that she forged from a specific perspective of critical legal thinking had been long in gestation in Black feminist thought as well as in the toil and struggles of black working women in the United States ${ }^{4}$. In the turmoil of the 1970s we can find for instance in the "Statement" of the Combahee River Collective (1977) a striking formulation of the problematic of intersectionality. Named after Harriet Tubman's raid on the Combahee River in South Carolina during the Civil War, which freed 750 enslaved people, the collective was a Black radical feminist and lesbian organization formed in 1974 (Taylor, 2017). As they write, their politics is defined by an active commitment "to struggling against racial, sexual, heterosexual, and class oppression" and they see as their "particular task the development of integrated analysis and practice based upon the fact that the major systems of oppression are interlocking" (ibidem: 15). This notion of "interlocking" systems of oppression clearly foreshadows intersectionality. At the same time, it calls attention precisely to the moment of "interlocking", which means to the junctures and articulation between them. "We also find it difficult", the collective writes, "to separate race from class from sex oppression because in our lives they are most often experienced simultaneously" (ibidem: 19). The concept of "identity politics" that readers can find in one of its earliest uses in the "Statement" of the Combahee River Collective has consequently quite different meanings than the ones that became usual later on. This concept is here a rallying and battle cry, urging Black women to focus on their "own oppression" and struggle for their own liberation, which would necessarily be a general liberation since "our freedom would necessitate the destruction of all the systems of oppression" (ibidem: 23).

Even long before the 1970s, the experience of the "interlocking" of racial, sexual, and class oppression had shaped the living experience of a multitude of black women in the United States. And it was contested in multifarious ways through struggles and organizing, first against slavery and then against lynching and segregation. While writings from the early stage of Black feminist thought (including such important names as Sojourner Truth and Ida B. Wells-Barnett) compose an important archive for anybody interested in the genealogy and prehistory of intersectionality (Gines, 2014), I would like to shortly dwell here on the debates about the condition of the Black proletarian woman in the Communist Party of the U.S.A. in the 1930s and in the 1940s. In the writings of Louise Thompson and Claudia Jones the questions of race and sex are indeed discussed from the point of view of the concept of exploitation, which will be later marginalized in the intersectional debate. Writing in 1936, Louise Thompson provides in Toward a Brighter Dawn a striking analysis of the condition of black women, focusing on a "Southern road," on "the plantations in the South", and on "Bronx Park, New York". The legacy of slavery runs through the whole article, which finds a dramatic apex in the description of the predicament of black domestic workers in the Bronx. Thompson speaks of a "slave market" in the Bronx, and casts it

4 See: Carasthatis (2016, chapter 1) and Bohrer (2019, chapter 0). 
as a "graphic monument to the bitter exploitation of this most exploited section of the American working population - the Negro women." And this is because they "meet this triple exploitationas workers, as women, and as Negroes" (Thompson, 1936).

More than a decade later, Claudia Jones, born in Trinidad and doomed to live and work in the U.K. after being deported from the United States in 1955, further develops such analysis. Her An End to the Neglect of the Problems of the Negro Woman! (1949) starts with an emphasis on the growth in the militant participation of black women "in all aspects of the struggle for peace, civil rights and economic security" (ibidem). It is in front of this intensified militancy that Jones calls for a new understanding of the role of black women and for an end to the neglect of that role permeating the labor movement. Jones dwells on the position of black women in different social spheres, from the family to mass organizations. She carefully analyzes in particular the condition of black domestic workers, focusing on the reasons that lead to the relegation of black women to "domestic and similar menial work" and stressing their "unbearable misery" (ibidem). She echoes Thompson writing that black domestic workers "suffer the additional indignity, in some areas, of having to seek work in virtual 'slave markets' on the streets where bids are made, as from a slave block, for the hardiest workers" (ibidem). Interestingly, she also analyzes the reasons that divide black and white women also within the working class. "White chauvinism" works as a boundary at the societal level, a boundary that crosses and divides also the composition of the working class. Even the experience of exploitation is hierarchized, as black women clearly demonstrate. As Jones writes, "not equality, but degradation and super-exploitation: this is the actual lot of Negro women!" (ibidem).

\section{FIGURES OF OPPRESSION}

"Triple exploitation" and "super-exploitation," the concepts introduced by Linda Thompson and Claudia Jones, are clearly attempts to use a Marxist language to come to terms with the specific condition of black working women. The proposed diversification and even hierarchization of exploitation raise however several problems. This is particularly the case when the notion of exploitation is understood in purely economistic terms and strictly connected to a narrow interpretation of "productive labor". Such an economistic concept of exploitation has long been prevailing in Marxism, including in the United States, and it allowed a subordination of all forms of oppression (for instance, in Thompson's words, oppression "as women, and as Negroes") to exploitation itself ("as workers") and to the related class politics. Consequently, several activists and scholars began to underscore the autonomy of those systems of oppression (say, sexism and racism) and to prioritize struggles against them, in many cases completely obscuring the relevance of exploitation. This is what characterizes the mainstream of debates on intersectionality, which are often shaped by a conceptual opposition between oppression and exploitation (Bohrer, 2019).

The important book by Patricia Hill Collins, Black Feminist Thought (originally published in 1990), joins a long tradition of theoretical reflection on the continuing legacy of slavery in defining the condition of African American women using the notion of oppression as the main conceptual reference of her analysis. It is worth quoting at length Collins' book on this point. "Oppression", she writes: 
"describes any unjust situation where, systematically and over a long period of time, one group denies another group access to the resources of society. Race, class, gender, sexuality, nation, age, and ethnicity among others constitute major forms of oppression in the United States. However, the convergence of race, class, and gender oppression characteristic of U.S. slavery shaped all subsequent relationships that women of African descent had within Black American families and communities, with employers, and among one another. It also created the political context for Black women's intellectual work" (Collins, 2000: 4).

Collins' theory of "intersecting oppressions" has been very influential in establishing the field of intersectionality (or "matrix of domination" as she preferred to say in 1990). It is easy to see that most "forms of oppression" mentioned by Collins (race, gender, sexuality, ethnicity...) are open to processes of multiplication form within, and a proliferation of figures of oppression indeed characterizes debates on intersectionality. Chicana feminism, for instance, introduced new perspectives into a discussion that was born out of the condition and struggles of black women $^{5}$, while the topics of sexual oppression and heteronormativity gained prominence in writings on intersectionality. This led to a kind of explosion of the field, which allowed multiple processes of subjective expression and constitution, shedding light on forms of domination that had long remained invisible, and productively widening the terrain of struggles for liberation. At the same time, it raised specific problems for a theory of intersectionality.

It is definitely true that, as Ashley Bohrer writes, intersectional theorists "have argued against additive and multiplicative models for their failure to highlight the mutual constitution of the structures of domination" (2019: 102). Nevertheless, it is important to remind that the notion of oppression in intersectional debates is characterized by an emphasis on "irreducibility" (of the single systems of oppression), which goes hand in hand with an emphasis on "simultaneity," i.e. with the claim that those systems "are experienced simultaneously and are inseparable" (Carasthatis, 2016: 57). There is a clear tension here, and while the critique of "single axis" thinking is a constitutive moment for theories of intersectionality, one can say that the principle of "irreducibility" has often tended to obscure the one of "simultaneity". What is at stake here is the risk of an identity politics that takes the specificity of a system of oppression as an exclusive framework not only for analysis but also for the process of subject constitution. The point is not to propose as an alternative a hierarchization of oppressions and consequently of struggles and claims, which is anathema to theories of intersectionality. It is rather to shift attention to the unitary moment in the working of systems of domination and oppression and to work toward the establishment of spaces of convergence for diverse and heterogeneous subjects. A focus on a specific system of oppression can well be an important moment in a process of subjectivation, even necessary to break processes of marginalization and to open up new vistas of liberation. Nevertheless, when the "identity" forged by such focus becomes frozen it paradoxically risks replicating the boundaries of the specific system of oppression it sets out to contest. And it becomes an obstacle to wider processes of subjectivation.

Within intersectional debates this problem is often addressed from the angle of a theory of coalition. "It was a while", writes Audre Lorde, "before we came to realize that our place was the very house of difference rather that anyone particular difference" (1982: 226). These words nicely encapsulate the point I just made on identity and identity politics. The "house of difference" can be a powerful image to describe an intersectional coalition, intertwining

5 See, for example: García (1997). 
solidarity and resistance toward a politics capable to bring "into being the worlds we really need" (Bohrer, 2019: 257). Such a coalition, as Bohrer rightly emphasizes (ibidem: 256), is necessarily different than being what is traditionally understood as the lowest minimum denominator among different groups. While in this case the subjectivity and identity of the collectives involved remain untouched, an intersectional coalition is a space of convergence for a multitude of diverse and heterogeneous people, within which new subjectivities and even identities are continuously fabricated in a common struggle for liberation. Needless to say, the very unity of a coalition is not given in advance, it is itself at stake in this process of subjectivation.

\section{CLASS, RELOADED}

The critique of the economistic notion of exploitation that I sketched above led to a marginalization of class, and even capitalism, in many debates on intersectionality. As it happened in cultural and postcolonial studies (Mezzadra, 2011), capital and capitalism were confined to the realm of "economy" while class was often identified with white, male, heterosexual workers in a standard employment relation. Differential systems of oppression like sexism and racism were considered to operate at the margins of capitalism, which could definitely instrumentalize the processes of hierarchization generated by them without ceasing to remain a fundamentally homogenizing power. I am convinced that such an understanding of capitalism is deeply flawed, and that a different way to look at the history and contemporary working of capitalism could provide us with an effective way to tackle the question of the "simultaneity" of systems of oppression raised by theories of intersectionality.

At stake here is first of all the question of the relation of capital with "difference" (Mezzadra and Neilson, 2019: 32-38). This is a question that has been reframed over the last years by historians of colonialism and global historians of labor, by postcolonial scholars and critical researchers working on the topic of development. There is an emerging consensus that what Lisa Lowe calls the "social production of 'difference"' (1996: 28) is a distinct and crucial moment in the operations of capital, which works in tandem with (and enables) the production of "abstract labor" as a norm for the reproduction of capitalism writ large. In my work with Brett Neilson (2013, 2019), I have argued that the interplay between difference and abstraction, or homogeneity and heterogeneity is particularly apparent in the working of contemporary global capitalism. This interplay regards in particular the question of labor. Following Marx's definition of labor power as "the aggregate of attitudes and capabilities" contained in the body, "the living personality of a human being" (Marx, 1976: 270), I contend that there is a need to emphasize the gap between the element of attitudes and capabilities and their "container", the body (Marx uses the German word Leiblichkeit, whose absolute materiality is not adequately rendered by the English translation with "physical form").

Such an emphasis on the body opens up new continents for the understanding of labor power as well as of its production as a commodity. What is at stake here is what we can call the production of subjectivity that is required for the very existence of that commodity. The differential fabrication of hierarchized bodies, where systems of oppression like sexism and racism have prominent roles to play, emerges as a crucial moment in the production of labor power as a commodity, which is according to Marx the cornerstone upon which no 
less than the existence of capitalism is predicated. The very boundary between production and reproduction, as well as between productive and unproductive labor appears tested and blurred from this point of view. And it is easy to see that a merely economistic understanding of capitalism and exploitation becomes untenable. The moment that I called of a production of subjectivity has rather multiple dimensions that must be acknowledged as internal to exploitation. We are confronted here with a panoply of (exploited) subjective figures, whose experience of oppression and exploitation is definitely mediated by different subject positions (where for instance racism, sexism, or heteronormativity can be prevailing) while their "simultaneity" is orchestrated by the operations of capital.

Class is today composed by this multitude of differences living, toiling, and struggling under the pressure of capital's exploitation. Multiplicity is the hallmark of class. While I emphasize the relevance of a non-economistic notion of exploitation for rethinking class today, there is a need to add that class politics today requires a panoply of movements and struggles that go well beyond the boundaries of class. Once we acknowledge the constitutive relevance for the working of exploitation of, say, racism and sexism, mobilizations against them, which may well include people who are not "exploited," are of the utmost importance -and can never be considered as addressing a kind of "secondary" contradiction-. Parallel to such transversal struggles there is a need to forge and practice new forms of solidarity and spaces of convergence, where intersectionality becomes a method for a multiplicity of encounters and for counteracting any ossification of identity politics. The latter can definitely play a positive role in opening up new fields of struggle but is always at risk of becoming an obstacle for wider processes of subjectivation - for building a more effective base for struggles against exploitation and oppression-. The notion of class, a "multitudinous class" or a "intersectional class" to put it with Michael Hardt and Toni Negri (2019: 84), provides a subjective name to that base and opens new lines of investigation and political intervention. And the reinvention of intersectionality that I mentioned above (as an "intersectionality of struggles", to remind the words of Angela Davis) seems to foreshadow a new politics of solidarity and even a new class politics.

\section{REFERENCES}

Ambedkar, B.R. (2016). The Annihilation of Caste. Ed. and annotated by S. Anand, London New York: Verso.

Bohrer, A.J. (2019). Marxism and Intersectionality. Race, Gender, Class, and Sexuality Under Contemporary Capitalism. Bielefeld: Transcript.

Carasthatis, A. (2016). Intersectionality. Origins, Contestations, Horizons. Lincoln and London: University of Nebraska Press.

Collins, P.H. (2000). Black Feminist Thought. Knowledge, Consciousness, and the Politics of Empowerment, second edition. New York and London: Routledge.

Crenshaw, K.C. (1989). Demarginalizing the Intersection of Race and Sex: A Black Feminist Critique of Antidiscrimination Doctrine, Feminist Theory, and Antiracist Politics. University of Chicago Legal Forum, 140, 139-167. 
Crenshaw, K.C. (1991). Mapping the Margins: Intersectionality, Identity Politics, and Violence against Women of Color. Stanford Law Review, 43(6), 1241-1299.

Davis, A. (2016). Freedom is a Constant Struggle. Ferguson, Palestine, and the Foundations of a Movement. Chicago: Haymarket Books.

Gines, K.T. (2014). Race Women, Race Men and Early Expressions of Proto-Intersectionality. In N. Goswami, M. O'Donovan \& L. Yount (Eds.). Why Race and Gender Still Matter: An Intersectional Approach (pp. 13-26). London: Pickering \& Chatto.

Haider, A. (2018). Mistaken Identity. Race and Class in the Age of Trump. London - New York: Verso.

Hardt, M., \& Negri, T. (2019). Empire, Twenty Years On. New Left Review, 120, 67-92.

Jones, C. (1949). An End to the Neglect of the Problems of the Negro Woman! In New Frame. Available at: https://www.newframe.com/from-the-archive-an-end-to-the-neglect-ofthe-problems-of-the-negro-woman/.

Lorde, A. (1982). Zami: A New Spelling of My Name. A Biomythography. Berkley, Calif.: The Crossing Press.

Lowe, L. (1996). Immigrant Acts: On Asian American Cultural Politics. Durham, NC: Duke University Press.

Marx, K. (1976). Capital, Vol. 1. New York: Vintage Books.

Mezzadra, S. (2011). Bringing Capital Back In: A Materialist Turn in Postcolonial Studies? InterAsia Cultural Studies, 12(1), 154-164.

Mezzadra, S. (2021). Challenging Borders. The Legacy of Postcolonial Critique in the Present Conjuncture. Soft Power, 7(2), 21-44.

Mezzadra, S., \& Neilson, B. (2013). Border as Method, or, the Multiplication of Labor. Durham: Duke University Press.

Mezzadra, S., \& Neilson, B. (2019). The Politics of Operations. Excavating Contemporary Capitalism. Durham: Duke University Press.

Nash, J.C. (2019). Black Feminism Reimagined After Intersectionality. Durham: Duke University Press.

Roediger, D. (1991). The Wages of Whiteness: Race and the Making of American Working Class. London - New York: Verso.

Roy, A. (2016). The Doctor and the Saint. In B.R. Ambedkar (Ed.). The Annihilation of Caste (pp.). London - New York: Verso.

Said, E.W. (1983). Traveling Theory. In The World, the Text, and the Critic (pp. 226-247). Cambridge: Harvard University Press.

Said, E.W. (1994). Traveling Theory Reconsidered. In Reflections on Exile and Other Essays (pp. 436-452). Cambridge: Harvard University Press.

Taylor, K.-Y. (2017). How We Get Free. Black Feminism and the Combahee River Collective. Chicago: Haymarket Books. 
Thompson, D. (2020). The Intersectional Politics of Black Lives Matter. In A. Dobrowolsky \& F. MacDonald (Eds.). Turbulent Times, Transformational Possibilities? Gender Politics Today and Tomorrow (pp. 240-257). Toronto: University of Toronto Press.

Thompson, L. (1936). Toward a Brighter Dawn. In Viewpoint Magazine (2015). Available at: https://viewpointmag.com/2015/10/31/toward-a-brighter-dawn-1936. 